\title{
Efforts in Improving Education Quality in Joko Widodo Presidential Era
}

\author{
Rendi Marta Agung ${ }^{1,}$ Ayu Niza Machfauzia ${ }^{2}$ \\ Yogyakarta State University, Sleman, Yogyakarta, Indonesia \\ rendimarta.2018@student.uny.ac.id¹,Ayu@uny.ac.id ${ }^{2}$
}

\begin{abstract}
Education is a pillar of a nation. A developed nation certainly has a good quality education. It cannot be denied that education is one of the keys to increasing national development. The main focus in the development of education until now is still on improving the quality and equity of education. The condition of education in Indonesia shows that the quality of education is still low. This is caused by several factors such as education costs, education disparity between urban and rural areas, and character education which is still concerning. The purpose of this study was to determine the policies made by the government in the era of President Joko Widodo. The study was conducted with qualitative methods and analytic observation of literature such as books, journals, reports, and newspapers. The results showed that the efforts made by the government to improve the quality of education in the era of President Joko Widodo consisted of 1) Program Indonesia Pintar (PIP), 2) Penguatan Pendidikan Karakter (PPK), and 3) Zonasi Pendidikan.
\end{abstract}

Keywords: Quality of Policy, Educational Policy, President Joko Widodo

\section{Introduction}

Undang-Undang Dasar (UUD) 1945 Pasal 31 that "every citizen has the right to education" that is, all Indonesian citizens without exception have the right to obtain a proper education. From year to year, the Indonesian government makes various efforts to provide decent and quality education to its citizens. It cannot be denied that education is one of the keys to increasing national development. The main focus in the development of education until now is still on improving the quality and equity of education. As quoted in Rencana Pembangunan Jangka Menengah (RPJMN) for 2015-2019, education development has several challenges such as accelerating the improvement of the level of education of all people in obtaining quality basic education services, and increasing access to education at secondary and tertiary levels, reducing inequality participation in education between socio-economic groups, between regions, and between sexes; and enhance lifelong learning [1].

Generally, the condition of the quality of education in Indonesia shows that in rural areas, especially remote areas, the quality of education is lower than in urban areas [2]. This is caused by several factors such as tuition fees. To get a quality education, it is recognized that it costs a lot of money. From kindergarten benches to community colleges, they have to pay expensive fees. Equitable access becomes discrimination because the people's ability to pay is not the same. Good education requires a lot of money. Educational services are the same as other public services. The better the service the higher the payment. For this reason, many children drop out of school, one of which is caused by their inability to pay tuition fees [3].

Another factor is the education gap between urban and rural areas. We can see this in big cities. Educational facilities and infrastructure are very advanced, while in rural areas there are 
still many inadequate facilities and infrastructure and even a lack of teaching staff, whereas good management of school facilities and infrastructure can improve the quality of education. Angka Partisipasi Kasar (APK) table below shows the gap between urban and rural areas.

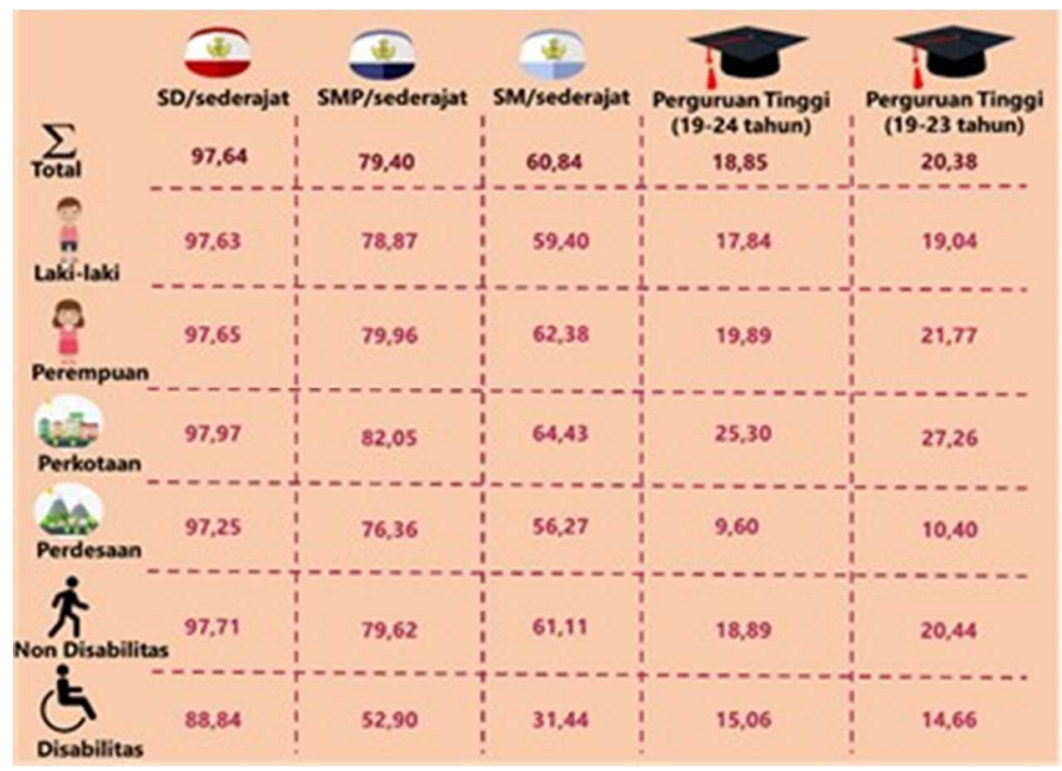

Fig.1. Angka Partisipasi Kasar

Source: Badan Pusat Statistik, 2019

Based on the data above, the APK level for elementary school/equivalent for urban and rural areas is already quite high, namely above $90 \%$ and there is only a small gap between urban and rural areas. However, the APK rate has declined along with the increase in education levels. Seen in junior high, high school and university levels, urban areas have a higher APK than rural areas. This shows the uneven education between urban and rural areas. Also, the decline in APK at the higher education level indicates the inability of the community to continue higher education due to being unable to pay for education costs.

Quality education is also inseparable from the role of students as the nation's building generation. The quality of education is not only assessed from school facilities, costs, and teachers but also is assessed from the character and character of students. The fact is that character education in Indonesia is still concerning, as reported by various media, there are many cases of students who disrespect their teachers. As happened in Kupang, Nusa Tenggara Timur (NTT) persecuted their teachers until they were battered. The reason was that the teacher reprimanded them for not having filled out the attendance list. The perpetrators were angry because they were reprimanded, they beat, stepped on the teacher's head, then threw him with a chair and a stone [4]. In addition to the physical abuse of teachers, other cases harass their teacher. This case occurred at SMK 4 Bogor while the school was doing a live broadcast of the Masa Pengenalan Lingkungan Sekolah (MPLS). At that time the video was showing a middle-aged female teacher wearing a pink headscarf and wearing glasses. However, it seems that many online MPLS participants are not serious about following the teaching and learning activities (KBM) agenda. At that time the comments column contained comments that were obscene and disrespectful [5]. 
This has made the government implement various policies to improve the quality of education in Indonesia. In the era of President Joko Widodo, there were several excellent programs that he carried out to improve the quality of education in Indonesia including Program Indonesia Pintar (PIP), Penguatan pendidikan Karkter (PPK), and Zonasi Pendidikan.

\section{Method}

According to Sugiyono, a naturalistic qualitative design studies the occurrence of activities and processes naturally, where this method is planned or manipulated [6]. Qualitative methods are generally focused on exploration, disclosure, and inductive logic. The inductive design begins with observation that is specific and built towards general pattern. Analytical dimensions arise from open-ended observation.

The data used in this research involved primary data, where data was directly obtained in data collection from a key informant. This data involved interviews with the key informant and supplementary informants. The second is secondary data obtained from other parties. This was indirectly obtained from the subject observed. The secondary data was obtained from analytical observation of literature comprising books, scientific journals, research reports, or newspapers.

\section{Results And Discussion}

\subsection{Smart Indonesia Program (Program Indonesia Pintar)}

One component that serves as a benchmark for the development of a country is education. Education plays an important role in the personal formation of students [7]. Education is an important agent in shaping the nation's personality [8]. The role of education is so great that there needs to be a solution that can answer these demands and challenges. One that supports the implementation of education is the provision of scholarships or educational support costs for students who are less able [9]. Departing from the importance of the existence of educational institutions for the success of education, the government should give optimal attention to all existing educational institutions, regardless of their background and status [10]. In Presidential Instruction No. 7 of 2014, mandates the Smart Indonesia Program to the Ministry of Education and Culture to prepare the Smart Indonesia Card (Kartu Indonesia Pintar).

From this action, Jokowi saw that there were gaps in Indonesian society that had not yet received an equal opportunity in education. In this case, Jokowi created a program to improve human resources by issuing the Smart Indonesia Card on November 3, 2014. is a strategic program to provide access to poor and vulnerable poor families who want to send their children aged 7-18 years for free. Those who get this Smart Indonesia Card will be given cash from the government regularly which is stored in the Smart Indonesia Card card function to go to school for free without charge. This program is a program of President Jokowi as a result of his attention to the people of Indonesia and also a form of future preparation for competition between countries which will be increasingly difficult [11].

The Smart Indonesia Program through the Smart Indonesia Card, is a continuation of the Poor Student Assistance (Bantuan Siswa Miskin/BSM) program which includes students from 
elementary / MI, SMP / MTs, SMA / SMK / MA, and students/residents studying at the Activity Center Learning / institutions and courses from households/families with the lowest economic status nationally. Based on these regulations, in the context of educational equality [12]; especially in providing opportunities for every child from underprivileged families to be able to stay in school, the government continues to improve access and quality of education to the community [13], as an effort to improve the quality of human resources that can build and advance the nation [14]. in order to achieve a knowledgeable, intelligent and character society [15]; through various development programs in the field of education financing, as a major investment in realizing sustainable development [16].

The government is expanding the scope of providing education cash assistance through the Smart Indonesia Program to improve the welfare of the underprivileged and encourage the continuity of education of children from underprivileged families [17]. With a wider scope, the government is trying to reach out to school children from underprivileged families, so they want to return to continue their education. Permendikbud No.12 of 2015 concerning the Smart Indonesia Program delivered in writing that; The Smart Indonesia Program is an education cash assistance aimed at school-aged children (6-21 years) [18]. The Smart Indonesia Program is the provision of cash assistance from the government to school-age children from underprivileged families, which is marked by the provision of the Smart Indonesia Card [19] . The Indonesia Smart Card is given to school-age children from families who have a Prosperous Family Card (Kartu Keluarga Sejahtera/KKS) to ensure that all school-age children can get education from elementary schools, junior high schools and senior high schools / vocational schools.

The effectiveness of government assistance in the form of the Smart Indonesia Program certainly attracts the attention of academics to research the allocation of government funds. Research conducted by Rohaeni (2018) shows that; PIP funds given to students in SMP Negeri 1 Manonjaya and SMP Negeri 2 Cineam Tasikmalaya, are managed properly by the technical guidelines, so that the constraints on the cost of education from students can be overcome [20]. There is also the misuse of the Smart Indonesia Program, as conveyed by Retnaningsih (2017), which states that PIP assistance in the City of Kupang and Palembang City is less than optimal, due to the intervention of the local political elite by forcing the names of students to be assisted [21]. Likewise with Hasan's research (2017), which shows that; the use of educational aid funds from the government, both through the Smart Indonesia Program and the Family Hope Program in SDN Jogosatru Sidoarjo is less effective, not on target and misused by some individuals [19]. Yusuf (2019) also said that there was a gap between the objectives of PIP implementation in SMP Negeri 7 Salatiga and the technical guidelines for implementing PIP from the government, which were reviewed in terms of design, process, products and their usefulness [22].

\subsection{Character Building (Pendidikan Karakter)}

Character education is the overall dynamics of the relationship between individuals with various dimensions, both from within and from outside themselves, so that the person can live up to freedom so that he can be responsible for his growth as a person and the development of others in their lives [23].

According to Sudirman et al [24], character education is a system of instilling behavioral values (characters) to school or campus residents which includes the components of knowledge, awareness or willingness and actions to carry out these values, both towards God Almighty, oneself, fellow environment and nationality so that it becomes plenary (human 
being). Character education is a comprehensive effort so that people understand, care, behave according to basic ethical values.

Implementation of Character Education To build a culture to shape the character of students, the steps that need to be done is to create an atmosphere of character (full of values) first. The creation of a character atmosphere is strongly influenced by the situation and conditions in which the model is determined along with the application of the underlying values. First, the creation of vertical (divine) character. This activity can be realized in the form of a relationship with Allah SWT, Almighty God, through increasing the quantity and quality of religious activities at school, such as praying in congregation, fasting Monday and Thursday, reading the Qur'an, praying together, etc. so. Second, the creation of horizontal character culture. This step is done by placing the school as a social intuition that when viewed from the structure of relations between people, can be classified into three relationships, namely: (1) superiors-subordinate relationships; (2) professional relations; and (3) equal or voluntary relationships based on positive values, such as brotherhood, generosity, honesty, mutual respect, and so on.

The development of education in realizing character culture in schools that are horizontal in schools can be done through a habituation approach, exemplary, and a persuasive approach or subtly inviting school residents, by giving reasons and good prospects that can convince them. The attitude of the activities is in the form of proxies, namely making their actions or initiatives, types and directions determined by themselves and reading the emergence of actions so that they can contribute to giving color and direction to the development of religious values in schools. It can also be in the form of anticipation, which is an active action to create ideal situations and conditions to achieve the ideal goals.

In more detail, the formation of positive characters can be done through the following four approaches. First, the instructional-structural approach, namely the strategy of character building in schools has become the commitment and policy of school leaders so that various regulations or policies that support the various character activities at school and its supporting facilities and infrastructure are included, including habituation. Second, the formal-curricular approach, namely the character-building strategy in schools is carried out in the integration and optimization of Teaching and Learning Activities (KBM) in all subjects and characters developed. Third, the mechanized-fragmented approach, namely the character formation strategy in schools is based on the understanding that life consists of various aspects, and education is seen as planting and developing a set of life values, each of which moves and runs according to its function. Fourth, the organic-systematic approach, namely character education is unity or as a school system that seeks to develop views or zeal based on values and ethics, which is manifested in life attitudes, behaviors, and life skills that characterize all school members [25].

\subsection{Educational Zoning Program (Program Pendidikan Zonasi)}

Getting proper education is the right of every Indonesian people without exception. For this reason, the government strives to provide decent quality education to its people. One of the policies implemented by the government is to implement an education zoning policy to ensure access and quality of education in Indonesia. Zoning is the division or splitting of an area or region into several sections, according to the functions and objectives of management. The zoning system of education is carried out to organize the school as a whole starting from kindergarten, elementary school, junior high school, and high school [26].

The zoning system of education is implemented in the implementation of New Student 
Admissions (Penerimaan Perserta Didik Baru/PPDB). This policy has been running since 2017 to equalize the quality of education, to eliminate the nickname of superior and nonsuperior schools. Zoning system provisions according to Permendikbud No. 14 of 2018 is the priority of prospective students (junior and senior high schools) that must be accepted, namely:

1. The distance of residence with school,

2. National Exam Results Letter (for junior high school graduates),

3. Academic and non-academic achievements.

Whereas for Elementary School level, the minimum age at school is the main provision, after that only the zoning system becomes the second provision [27].

The zoning system policy in the Acceptance of New Students regulated in Permendikbud No. 14 of 2018 states that schools must accept at least $90 \%$ of students domiciled in the zone according to local government regulations. Therefore students do not need to go to a school far from where they live. Then what about those high achieving students who want to go to a certain school? schools can still accept students outside of zoning provided that the reasons for achievement are at most 5\% and special reasons such as the parent domicile transfer at most $5 \%[28]$.

Before applying the education zoning system policy, the implementation of New Student Admissions was carried out using the highest value derived from the report card grades and test scores. This led to the emergence of the term "favorite school or superior school". Because of this term, many new students compete with one another to be able to go to "favorite school or superior school". This hurts schools that are less favorite so that the number of new students who register becomes and makes the school a shortage of students.

The education zoning program is felt to more evenly spread the education gap between favorites and non-favorite schools as well as urban and rural schools. Favorite school labels in some areas make schools compartmentalized. Through the education zoning program, it is expected that the quality of education in both cities and villages can be evenly distributed. Because learning is a process where students who have not been able to be able to do something like absorbing learning in school.

\section{Conclusions}

Based on the results of the analysis, it can be concluded that education is one of the keys to the success of a country. Every leader strives to improve the quality of education in his leadership era, including President Joko Widodo. In the era of leadership, there are several programs that he has implemented to improve the quality of education, namely: The Smart Indonesia Program (PIP), through the PIP, the government is budgeting funds to help fund students and the Indonesia Smart Card with a nominal amount sufficient to assist the learning process so that there are no more dropouts because there are no fees.Character Building Strengthening Program, where education is centered in 3 scopes, namely family, school, and community. Where the nation's character will be formed with good character education.Educational Zoning Program, where the occurrence of educational equality is not only in the city, but schools in the periphery also get students who excel and not far from school and home.The three programs are efforts by the government to provide decent and quality education to Indonesian citizens. 


\section{References}

[1] Badan Pusat Statistik, Potret Pendidikan Indonesia Statistik Pendidikan 2019. Jakarta: Badan Pusat Statistik, 2019.

[2] U. \& L. S. Tirtarahardja, Pengantar Pendidikan. Yogyakarta: PT Rineka Cipta, 2013.

[3] C. Aoer, Masa Depan Pendidikan Nasional. Jakarta: Center for Poverty Studies, 2005.

[4] "Tak Cuma Pukul, 3 Pelajar SMA di Kupang Lempari Guru Pakai Batu dan Kursi."

[5] "MPLS Online, Bocah Komentar Cabul ke Guru Langsung Bikin Klarifikasi - Bagian 1." [Online]. Available: https://jogja.suara.com/read/2020/07/14/080934/mpls-online-bocahkomentar-cabul-ke-guru-langsung-bikin-klarifikasi. [Accessed: 10-Aug-2020].

[6] Sugiyono, Metode Penelitian Pendidikan. Bandung: Alfabeta, 2018.

[7] D. Arif and N. Pratama, "Al-Tanzim : Jurnal Manajemen Pendidikan Islam Tantangan Karakter Di Era Revolusi Industri 4.0 Dalam Membentuk Kepribadian Muslim,” AL-TANZIM J. Manaj. Pendidik. Islam, vol. 03, no. 01, pp. 198-226, Jun. 2019.

[8] A. Erwinsyah, "Manajemen Pembelajaran Dalam Kaitannya Dengan Peningkatan Kualitas Guru," 2017.

[9] S. Kurniawan, "Pengembangan Manajemen Mutu Pendidikan Islam Di Madrasah," AL-TANZIM J. Manaj. Pendidik. Islam, vol. 1, no. 2, pp. 25-36, Sep. 2017.

[10] W. B. Yusup, B. Ismanto, and W. Wasitohadi, "Evaluasi Program Indonesia Pintar dalam Peningkatan Akses Pendidikan di Sekolah Menengah Pertama," Kelola J. Manaj. Pendidik., vol. 6, no. 1, pp. 44-53, Jun. 2019.

[11] P. Jhoshella, "Gaya Komunikasi Jokowi Dalam Program Kartu Indonesia Pintar," Natl. Conf. Creat. Ind., Sep. 2018.

[12] M. Idrus, "Mutu Pendidikan Dan Pemerataan Pendidikan Di Daerah," Psikopedagogia J. Bimbing. dan Konseling, vol. 1, no. 2, Dec. 2012.

[13] . S., "Penerapan Fungsi-Fungsi Manajemen Dalam Meningkatkan Mutu Pendidikan," Idaarah J. Manaj. Pendidik., vol. 1, no. 1, Jun. 2017.

[14] I. K. Rachmawati, Manajemen Sumber Daya Manusia. Yogyakarta: C.V. Andi Offset, 2008.

[15] A. W. Dodd, "Educating for Character: How Our Schools Can Teach Respect and Responsibility. By Thomas Lickona. New York: Bantam Books, 1991," NASSP Bull., vol. 76, no. 545, pp. 119-120, Sep. 1992.

[16] N. D. William, Pengantar Analisis Kebijakan Publik. Yogyakarta: Gajah Mada University Press, 2017.

[17] A. Ahmad, "Kinerja Program Indonesia Pintar Melalui Kartu Indonesia Pintar (Survei Pada 6 Provinsi di Indonesia)," May 2018.

[18] “(No Title)." [Online]. Available: https://jdih.kemdikbud.go.id/arsip/permendikbud_tahun2015_nomor012.pdf. [Accessed: 11Aug-2020].

[19] "Efektivitas Penggunaan Dana Bantuan Pendidikan | MODELING: Jurnal Program Studi PGMI." [Online]. Available: https://jurnal.stitnualhikmah.ac.id/index.php/modeling/article/view/102. [Accessed: 11-Aug2020].

[20] N. E. Rohaeni and O. Saryono, "Number 1 Indonesian Journal of Education Management and Administration Review," Jun. 2018.

[21] H. R.-A. J. M. Sosial and undefined 2019, "Program Indonesia Pintar: Implementasi Kebijakan Jaminan Sosial Bidang Pendidikan," jurnal.dpr.go.id.

[22] W. B. Yusup, B. Ismanto, and W. Wasitohadi, "Evaluasi Program Indonesia Pintar dalam Peningkatan Akses Pendidikan di Sekolah Menengah Pertama," Kelola J. Manaj. Pendidik., vol. 6, no. 1, pp. 44-53, Jun. 2019.

[23] D. K. A, Pendidikan Karakter Strategi Mendidik Anak di Zaman Global. Jakarta: PT Gramedia, 2011.

[24] Sudirman, Buku Panduan Mata Kuliah Pendidikan Karakter. Yogyakarta: Fakultas Sosial dan 
Ekonomi UNY, 2010

[25] R. A. Abdillah Dalimunthe, "Strategi Dan Implementasi Pelaksanaan Pendidikan Karakter Di Smp N 9 Yogyakarta," J. Pendidik. Karakter, vol. 0, no. 1, Apr. 2016.

[26] N. S. Perdana, "Implementasi Ppdb Zonasi Dalam Upaya Pemerataan Akses Dan Mutu Pendidikan," J. Pendidik. Glas., vol. 3, no. 1, p. 78, Apr. 2019.

[27] D. W.-P. P. B. K. D. RI and undefined 2018, "Peningkatan Kompetensi Guru Menuju Era Revolusi Industri 4.0."

[28] A. A. Safarah and U. B. Wibowo, "Program Zonasi Di Sekolah Dasar Sebagai Upaya Pemerataan Kualitas Pendidikan Di Indonesia," Lentera Pendidik. J. Ilmu Tarb. dan Kegur., vol. 21, no. 2, p. 206, Dec. 2018. 